\title{
Land Tenure Insecurity and Inequality in Nicaragua
}

\author{
Rikke J. Broegaard
}

\begin{abstract}
This article uses empirical data from a case study in rural Nicaragua to demonstrate the need for a conceptualization of tenure security as seen from the perspective of the landholder. A large group of farmers in the case study area perceive their tenure situation as being insecure despite the fact that they possess a legal title to their land. The article argues that more attention must be paid to aspects such as inequalities of wealth and power, lack of enforcement and lack of impartiality on the part of the formal institutions when addressing tenure security in an institutionally unstable setting, such as that found in Nicaragua. The article contributes to the ongoing discussion by arguing that future research on how to increase rural land tenure security should explore the concept of tenure security as experienced by farmers.
\end{abstract}

\section{INTRODUCTION}

Problems of social inequity and conflicts are closely intertwined with land tenure insecurity, conflicting property claims and the unequal distribution of land throughout rural areas of the developing world. As a result, efforts to ensure or increase poor people's access to and control over land are a question of broad social importance. This article focuses on the theoretical concept of tenure security as perceived by farmers, including the farmers' subjective evaluation of their current land tenure security as it relates to their possession or lack of (different types of) land titles, as well as expectations about (state) enforcement of property rights. The concept of perceived tenure security is especially relevant, as it takes into account the consequences of the inequalities of wealth and power, as well as local interpretations of specific historical experiences.

This research was supported by the Danish Institute for International Studies, the Network for Development-related Soil Science within the Danish Council for Development Research, and the North/South Foundation of the University of Copenhagen. The author is grateful to Helle Munk Ravnborg, Jannik Boesen, Dorte Thorsen, Kjeld Rasmussen and Kate V. Gough for comments during the research; to Monique Nuijten, Christian Lund, Thorkil Casse and Rasmus Heltberg for comments during the final phase of the paper; and to the two anonymous referees for their helpful suggestions. The usual disclaimers apply.

Development and Change 36(5): 845-864 (2005). (C) Institute of Social Studies 2005. Published by Blackwell Publishing, 9600 Garsington Road, Oxford OX4 2DQ, UK and 350 Main St., Malden, MA 02148, USA 
The article builds on a case study from Nicaragua, but the findings from this case study are more widely relevant, as they illustrate mechanisms and concerns that also exist elsewhere, although their extent and concrete expression will depend on the specific context. Within Nicaragua, the case study is not an extreme case: power abuses and difficulties in getting access to state institutions are even more pronounced in some remote parts of the country. However, the case study should not be seen as representative for a wider area of Latin America, since the history of Nicaraguan land tenure has been exceptionally turbulent.

The following section discusses different approaches to land tenure security, ranging from economic and institutional to anthropological. After a general discussion of the advantages, including the perceived tenure security in the discussion of land administration and titling efforts to ensure small scale farmers' control over land, the article presents and compares the perceived land tenure situation of farmers with different legal tenure situations in the Nicaraguan case-study area. It then analyses two landownership histories, and discusses the shortcoming of land titles in providing or increasing (perceived) tenure security — security being not a dichotomous phenomenon but a gradual concept of more or less. Finally, the article examines several elements that could potentially contribute to tenure security. Findings from the case study area demonstrate the need to take into account elements of perception, specific historical context, and power and wealth inequalities in the conceptual framework of any tenure security analysis.

\section{TITLING FOR SECURITY}

A frequently used justification for land titling and land administration projects is that they either increase or guarantee poor people's access to secure land tenure (Deininger et al., 2003). For decades, it has been argued that land titles are needed to reduce or eliminate uncertainty that landowners might have about land ownership. ${ }^{1}$ This 'security rationale' rests on three expected outcomes of land titling, namely: (1) the demarcation or clarification of physical boundaries of the property and associated property rights; (2) the availability of more information on property issues due to registration of property rights and cadastral information; and (3) a titleissuing entity and related institutional setup (for example the state) that ensures the enforcement of those property rights (Lemel, 1988). These elements form the basis for enforcement of property rights.

1. That is, titles are assumed to increase tenure security; see Feder and Feeny (1991); Feder et al. (1988); World Bank (1999). 
It is often argued that when the titleholder can reasonably expect his or her property rights to be enforced, he or she will have stronger incentives to make long-term property investments. This, combined with better access to formal credit, is expected to lead to higher levels of investment in agriculture, higher production, as well as higher land prices and a better-functioning land market. From this, land would theoretically be allocated to the most efficient land user (Binswanger et al., 1995; Feder and Feeny, 1991). This process is depicted in Figure 1, which offers a schematic presentation of the 'conventional' view of relationships between land titles, tenure security, investments, credit access and the land market.

There is general agreement that land titles and clarity of property rights and property boundaries do play a major role in providing tenure security, and that tenure security is important for providing incentives for investments in land use (Bruce and Migot-Adholla, 1994). An influential study by Feder et al. (1988) in Thailand concluded that land titles create tenure security and provide better access to and larger amounts of formal credit, as well as higher levels of investment in the land and higher land prices. Other studies have supported their findings. ${ }^{2}$ However, it is worth noting that Carter and Olinto (2003) only identified the positive effect of land titling on medium and large farms: the small-scale farmers do not seem to benefit from titling to the same extent as wealthier farmers. In a context such as Nicaragua, where almost half of the landowners own less than

\section{Figure 1. The 'Conventional' View of Land Tenure Relationships}

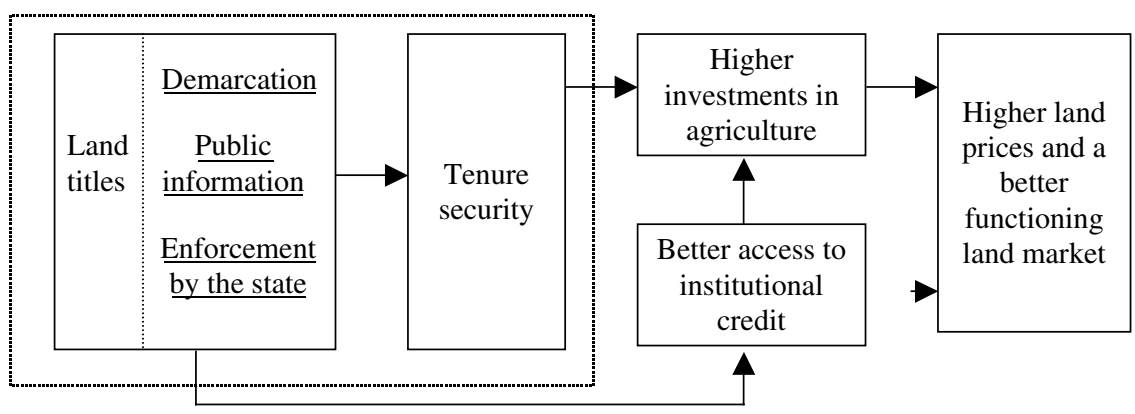

Note: The highlighted box indicates the focus of the present article.

2. In Latin America see, for example, Deininger and Chamorro (2002) for Nicaragua, Alston et al. (1996) for Brazil, and Carter and Olinto (2003) for Paraguay. Carter and Olinto (2003) use panel data to compare situations on the same land holdings before and after titling, and in comparison to a non-titled control group, which allows for very good control of farmer-specific characteristics. 
10 manzanas $^{3}$ of land (CENAGRO, 2001), it is therefore relevant to look further into what impact land titles have on tenure security and other expected outcomes of titling. Furthermore, there is little consensus concerning which elements are the most important in contributing to land tenure security and exactly what role land titles play in this, as African-based studies, especially, have pointed out.

This conceptual framework of land tenure security was developed mainly by economists. Over the last decade, a re-conceptualization has emerged through the integration of findings from (legal) anthropologists and historians (for example, Juul and Lund, 2002; Li, 1996; Moore, 1999; Rose, 1994). This new focus recognizes that the inherent social and economic complexities of property rights and tenure security (and the shortcomings of the state) must be included in the conceptual framework for dealing with tenure security. The re-conceptualization brings into the debate the idea that a lack of individual land titles does not necessarily mean that the land tenure is insecure, and that individual, formal titles may not significantly strengthen tenure security (Jansen and Roquas, 1998; Lemel, 1988; Place and Hazell, 1993; Place et al., 1994). This is because other elements, such as social networks, local norms and duration of possession, may actually create a high degree of tenure security, regardless of the possession of formal land titles (Coles-Coghi, 1993; Roquas, 2002). An institutionally-inspired critique of the previous approach to tenure security argues that it has unrealistic expectations regarding the enforcement of land rights (including those formally recognized with land titles), which in real life situations can present a serious problem (Bromley, 1991; Lemel, 1988; Ostrom, 2001). The new conceptual framework recognizes that corruption, high costs of land titles and a very expensive legal system preclude effective and equal enforcement of land titles, especially for poor, small-scale farmers. A more contextspecific conceptual framework is thus required.

Another basic but critical aspect that is often overlooked is that in order for someone to use land titles for ensuring their rights to a piece of land, they require access to social, economic and political resources (Broegaard, 2000; Coles-Coghi, 1993; Wachter, 1997). Limitations on these resources may prevent poor households from obtaining the necessary support from formal state institutions to enforce their property rights, despite possessing a land title. Conversely, farmers with sufficient economic or political resources can claim, formalize and enforce land rights, regardless of the original legal tenure situation of the land, as shown below. As a result, land titles appear to provide a feeling of tenure security mainly to the wealthy landholders (GTZ, 1998; see also Carter and Olinto, 2003).

The emerging re-conceptualization of the relationship between land titles and land tenure security also emphasizes existing differences of wealth and

3. 1 manzana $=0.7$ hectares. 
power between households, ${ }^{4}$ implying that land titles can provide tenure security to some households, but not to others (Jansen and Roquas, 1998). Influential econometric studies of land tenure in the late 1980s treated the possession of legal title as being equal to tenure security (for example, Feder et al., 1988). This operational simplification suggested that households which possessed a land title were secure, whereas those households without such a title were not. However, this focus sidestepped the fact that, in many contexts, title possession is not necessarily equated with having a high level of tenure security (Broegaard, 2005; Coles-Coghi, 1993; Jansen and Roquas, 1998; Roquas, 2002; Wachter, 1997). The importance of the complex relationship between titles and security has increasingly been recognized in recent economic studies of land tenure (such as Carter and Olinto, 2003; de Laiglesia, 2004). The empirical analysis of this relationship is especially important in situations where institutional pluralism exists, whereby several institutions are competing over the authority to recognize property claims as rights (Lund, 2001). By assuming that titles meant tenure security, some earlier studies focused their empirical analysis on the link between titles and investment, while the interrelationships between different possible institutional recognitions of property rights, perceived tenure security, and levels of investment were overlooked or ignored. ${ }^{5}$

One basic assumption of the benefits of titling and land administration is that land titles create tenure security through the registration of demarcated land plots and thereby increase the level of publicly available information. In turn, this creates a basis upon which land rights can be enforced. It generally follows that the state is the guarantor of the enforcement of these rights. However, as the case study from Nicaragua will show, there are often shortcomings in the state's capacity (and interest?) to be such a guarantor of the equal enforcement of property rights, which have to be taken into account. ${ }^{6}$ Theoretically, those institutions responsible for recognizing the validity of a land title should take action to ensure that relevant authorities enforce the property rights, as well as sanction the cases where property rights are violated. However, for enforcement to be efficient there must be transparent, easy and equal access to these institutions, even for poor, rural farmers. Furthermore, there must not only be a high probability that any violation of the rights will be sanctioned, but also the sanctions must be sufficiently strong to make property rights violations an unrewarding crime (Bromley, 1991; Ostrom, 1990). The level of enforcement and efficiency of sanctions are

4. This movement is also noticeable within the research department of the World Bank: see Binswanger et al. (1995); Deininger (1999); Deininger et al. (2003); Pagiola (1999).

5. For inspiring discussions of how investments may influence tenure security, see, for example, Braselle et al. (2002); Rose (1994) and Sjaastad and Bromley (1997).

6. For interesting studies on titling efforts and tenure security, see Merlet and Pommier (2000) for Nicaragua, and Coles-Coghi (1993), Jansen and Roquas (1998), and Roquas (2002) for Honduras. 
thus important assumptions for the conventional land title/tenure security argument. Land titles are likely to be of less importance for tenure security where enforcement is repeatedly lacking, where the formal juridical system is unfair or where there is a lack of conflict-resolution mechanisms, and where there is simply a general distrust in the formal rights and enforcement system (Pagiola, 1999).

In relation to a large-scale titling project in Honduras in the 1990s, ColesCoghi (1993: 168) finds that: 'In the highlands of Honduras, the acknowledgement of tenure security still relies more on the existence of community recognition rather than on State granted documents'. Through his analysis, Coles-Coghi concludes that:

[the] problem with legal practices so far developed [by State and donors] is that they are complex, remote, costly, difficult to access and lacking in legal clarity and security. ... [Therefore] the farmer's resistance to using the legal procedures... has the potential for serious repercussions for the future of the land tenure security... transforming a project that aimed at improving the tenure security into one that instead fosters insecurity, since under such circumstances, customary transfers in INA-PTT titled land, have become, in the eyes of the State law, illegal transfers. (ibid.: 171) ${ }^{7}$

\section{THE CONCEPT OF PERCEIVED TENURE (IN)SECURITY}

The extent to which a farmer feels secure regarding his or her present and future land tenure is central for decisions on long-term investments in the land. This is intuitively appealing, as future land tenure is necessary in order for the farmer to be able to harvest the fruits of his or her investments (Bromley, 1991). However, the impact of having (or lacking) different types of land titles on (in)security is likely to differ from one type of threat to another. It is thus a question of empirical evaluation rather than theoretical assumptions whether, or to what degree, farmers without titles feel insecure, and to what extent the possession of title creates tenure security.

There is a wide range of threats to farmers' tenure security. These include disputes over boundaries with neighbours or co-operative members; inheritance settlements; access-rights and ways-of-passage; land-grabbing by powerful elites, whether rural co-operative chairmen, urban-based cattle owners or lawyers; invasion of land by landless; and government expropriation. In this study, perceived tenure security is defined as a composite concept combining the farmers' own assessment of their tenure situation when asked directly, and their fears (or absence of fear) for future conflicts regarding their property rights. It is assumed that farmers' assessment of their tenure security level will be influenced by their subjective understanding of their legal tenure situation, their general expectations regarding

7. See also Stanfield et al. (1986) on land tenure security in Honduras and Nuijten (2003) for illegal shadow procedures in the context of a Mexican ejido. 
government enforcement and equality of the law, as well as their assessment of their access to the government institutions they might need in case of a land conflict. ${ }^{8}$

By applying the concept of tenure security as seen from the perspective of the landholder, this study attempts to provide a broader understanding of the elements involved in securing access and claims to land, than that which is possible with a strictly legalistic approach. The perceived tenure security may not necessarily coincide with the legal tenure situation, just as perceived (in)security may differ from 'objective' measures of (in)security, such as (low) frequency of land conflicts, court cases and evictions. Whatever the legal situation of a piece of land, it is the perceived tenure situation that forms the basis upon which the landholder can be expected to take decisions and to act (Jansen and Roquas, 1998; Migot-Adholla et al., 1991; Place et al., 1994; Sjaastad and Bromley, 2000). The main reason for this is that people do assume that moral or socially defined rights exist and they behave accordingly, regardless of whether these are in accordance with formal rights (Freeden, 1991). Based on the above, tenure security is defined in this article as the farmers' perception of having tenure security.

\section{The Case Study: Methods}

The fieldwork for this study was carried out in 1999 in three neighbouring villages, ${ }^{9}$ Las Brisas, La Manzana and El Rincón in southwestern Nicaragua. A combination of qualitative and quantitative methods was used, covering a total of 349 households.

The first phase of the fieldwork was made up of in-depth conversational interviews, focus group discussions and map-drawing exercises, as well as the elaboration of a complete population census. Informants for the in-depth interviews were selected to represent as wide a range of different land tenure and living conditions as possible (see Ravnborg, 1999 for maximum variation sampling). Additional households were selected to include the different village leaders, such as members of the village committee, co-operative leaders, leaders of the farm workers' union, local promoters of NGOs, religious leaders, and the few wealthy or otherwise powerful landowners in the area.

A questionnaire survey was carried out for all seventy-one households in La Manzana. Census and key tenure data were obtained for all households in the entire case study area. The fieldwork was finalized with a second round of in-depth interviews, which not only included field visits to discuss

8. Past experiences with land conflicts will also influence their assessment, but no clear relationship between conflict experiences and perceived tenure situation can be expected, as this depends on the exact outcome of that experience.

9. The names of all persons, villages and the municipality are fictitious. 
land use practices and tenure issues with the land users on their plot of land, but also informal talks with a large number of households in all three villages. Additionally, data were searched for in public registries, the cadastral office, archives, the mayor's office and local land-use regulating units. Finally, NGOs working in the villages, and professionals within the municipality, as well as in NGOs, government institutions and research institutions at the regional and national level, were also interviewed. ${ }^{10}$

\section{The Nicaraguan Context: Post-War and Post Land Reform}

Land conflicts have been a characteristic of the history of Nicaragua for decades. A land reform in the 1980s under the Sandinista government affected about one-third of the country's area, but often without the land having first been properly transferred into property of the State. This has led to ongoing counter-claims and extremely high compensation costs for the state; 83 per cent of the rural properties under review after the 1990 change of government were still pending or on appeal by mid-2001 (EIU, 2001). Furthermore, corruption amongst current politicians and within government institutions contributes to a high level of mistrust in these institutions and their impartiality.

Las Brisas, La Manzana and El Rincón are situated in the rural part of the municipality of San José, which is located in the southwest of Nicaragua. The region is one of the most densely populated departments ${ }^{11}$ in Nicaragua. It has a relatively well-extended infrastructure of roads, and is quite close to the capital Managua as well as important provincial commercial centres. Compared with other parts of Nicaragua, it has a long tradition of intensive agriculture, including fruit, coffee, cacao and vegetables. Agricultural production by small-scale farmers (minifundistas) is mainly directed towards home consumption, and the primary crops are maize, beans, cassava, and plantains, supplemented with a large number of fruits and vegetables, as well as poultry and small livestock. Because of their far superior access to capital, credit, political support and technology, the largescale farmers (latifundistas) are able to apply a very different set of production strategies, mainly producing export crops, led by sugar cane, cattle and coffee.

10. The qualitative data were analysed using NUD*IST, while the data obtained through the questionnaire survey were entered into a database and analysed using SPSS, employing various types of bi- and multivariate analysis procedures. The multivariate statistical procedures used here, homogeneity and cluster analysis, have combined several related variables into a single set, which describes the element in question more precisely. The procedure was developed by the Department of Data Theory at the University of Leiden, The Netherlands (SPSS, 1994).

11. In Nicaragua, departments are equivalent to regional or district level administrative units. 
The large majority of the households in the three case-study villages depend for their livelihoods on agriculture supplemented with paid farm work, as well as temporary migration to plantations outside the region. The three neighbouring villages are within a couple of kilometres of each other, and are very similar in terms of population, agriculture, employment and socio-economic structures. Together, the three villages form an administrative sub-unit in the San José municipality, the comarca El Rincón.

In each village an agricultural co-operative was formed on land that was confiscated after the Sandinsta Revolution. The co-operatives in the case study area were given a legalized and registered collective land title, as well as extremely favourable loan conditions from the Sandinista government. After the change of government in 1990, institutional credits were virtually discontinued for the co-operatives and small-scale farmers, and agricultural policies changed profoundly, forcing many co-operatives to sell parts of their land to pay off debts. ${ }^{12}$ Today, the co-operatives have been dissolved, dividing the remaining land and capital among the members. Some cooperatives formalized the individual landholdings and got an individual land title for each member. In other co-operatives the members still depend on one collective land title, although the land has de facto been split up into individual plots. Apart from economic hardship and most farmers' preference for farming independently, the dissolution of the co-operatives was further stimulated by abuses of power and information by the leadership of many co-operatives. In each village there is also a small-scale private farming sector and a few very large private landholdings.

\section{Findings and Analysis}

\section{Insecure and Unequal Tenure}

Of all the landowning households in La Manzana, 44 per cent evaluate their land tenure situation as insecure or worrisome. Almost one in five landowning households has experienced claims against their land, either at the time of the research or previously. The perceived land tenure insecurity is even more pronounced in Las Brisas and El Rincón, mainly due to more frequent land conflicts. These data on perceived land tenure insecurity in the case study area are alarming, but they correspond with an estimate of land tenure insecurity in Nicaragua which indicates that 25-40 per cent of all Nicaraguan households were involved in conflicts over property rights, or in potential conflicts (Stanfield, 1995). In parallel, Merlet and Pommier (2000)

12. Even when the co-operative was still functioning, large areas were sold to help cover old debts: the collective land reform title does not necessarily guarantee that the land is not sold. See Jonakin and Enríquez (1999) for a discussion of the credit situation. 
found that 20 per cent of plots studied in different parts of Nicaragua suffered from some land conflict.

Access to land in the case study area has been gained in three main ways: through the market, through the family and other social institutions (such as inheritance, pre-inheritance or loans from a patrón), and through the previous land reform programme (see also Stanfield and Hendrix, 1993). These access mechanisms are closely, but not completely, related to the different types of tenure documents in the case study area. These comprise a mixture of tenure documents with varying degrees of formality, accuracy, registration and individualization. In this study they are categorized as formal individual land titles, informal tenure documents and collective land reform titles. Individual land titles are the dominant form of tenure documentation found in the case study area, in just over one-third of the landowning households. However, almost as many landowning households - just less than one-third of the total - depend on informal tenure documents (that is, non-actualized documents that are frequently in the name of a relative or a former owner), and some have no papers for their land at all. A similar proportion of the landowning households depend on collective land reform titles as being the most formal kind of documentation for their land rights. ${ }^{13}$

The distribution of land in the case study area is highly unequal (see Table 1), which is also true of Nicaragua in general, despite decades of land reform (Deininger et al., 2003). More than 40 per cent of the households are landless and the median value of landholdings is just half of a manzana. The land-poorest two-thirds of the households own 5 per cent of the total area, while the land-richest 6 per cent of the population own more than two-thirds of the area. Not surprisingly, the size of landholding is positively related to

Table 1. Landholding Size Categories: Frequency and Distribution Relative to Total Area (Las Brisas, La Manzana and El Rincón)

\begin{tabular}{|c|c|c|}
\hline $\begin{array}{l}\text { Landholding size, } \\
\text { categories }\end{array}$ & $\begin{array}{c}\text { Number of households } \\
(\% \text { of total })^{\mathrm{a}}\end{array}$ & $\begin{array}{c}\text { Area in } \mathrm{mz} \\
(\% \text { of total area })^{\mathrm{b}}\end{array}$ \\
\hline Landless ${ }^{c}$ & $152(44)$ & $0(0)$ \\
\hline$<3.5 \mathrm{mz}$ & $86(24)$ & $154(6)$ \\
\hline $3.5-10 \mathrm{mz}$ & $60(17)$ & $366(10)$ \\
\hline $10-50 \mathrm{mz}$ & $30(9)$ & 609 (17) \\
\hline$>50 \mathrm{mz}$ & $20(6)$ & $2438(68)$ \\
\hline
\end{tabular}

Notes:

a) Total number of households studied $=349$.

b) Total area of Las Brisas, La Manzana and El Rincón = $3566 \mathrm{mz}$.

c) This category includes the households that rent land on a short-term basis.

Source: author fieldwork

13. Some households possess several plots of land, obtained in different ways and with correspondingly different land tenure documents. The study categorizes the households according to the most formal tenure document owned. 
indicators of economic wealth such as capital, cattle, economic income, and housing standard.

\section{Land Ownership Histories}

\section{In order to illustrate some of the forms of land ownership and the issues of tenure security in the case study area, it is worth looking more closely at the situation of some of the individuals in the selected villages.}

Roberto and Zulema are full-time farmers. They own three pieces of land and rent a couple of other plots, all of which are cultivated together with their three grown-up sons. Roberto and Zulema bought the house plot a few years after they married; the original purchase was based on a verbal agreement and Roberto didn't even have a receipt for the money paid. He had to put pressure on the vendor, and eventually had to pay her extra money, in order to obtain the papers. After this experience he learned to ask for written proof of any transaction. During the Sandinista revolution in the 1980s Roberto became part of the co-operative for four years, but left because he could earn much more by working in a sugar plantation and at the same time renting land and cultivating it, thereby adding to the family's food security. After a good year with much employment and a good harvest, he would invest the money in cattle or oxen, which is still the way he saves up.

In 1993 he got the chance to buy a plot of land of 5 manzanas, located just outside the village. He sold the family's oxen to pay for the land. The land cost 22,500 Córdobas, but soon after the sales agreement had been signed (an informal paper stating the sale of the land and the amount of money paid) the seller regretted the sale and tried to force Roberto to cancel the deal. Roberto was threatened with a court case for claims made by relatives of the seller. As a result of good luck and support from relatives and friends within the police, and despite not belonging to the same political party as the local judge, Roberto succeeded in having the case against him suspended. After these incidents, he spent 5,000 C\$ to sort out the paperwork for the property, as he felt this was necessary to reduce the risk of losing the entire investment in the land. Apart from the economic cost, Roberto spent a lot of time making trips to the provincial capital in order to meet lawyers, have the land measured, a cadastral map produced, and the property inscribed in the Property Registry.

In 1994 Roberto had the chance to buy more land, this time 6.5 manzana located at some distance from the village. The land was cheap (1,000 Córdobas per manzana), partly because the land was from the former co-operative and the beneficiaries of the land reform were afraid of losing their land after the 1990 change of government. Some of the beneficiaries thus chose to sell the land, despite having individual land titles to the land. The price was also low because of the steep relief of the land, and the fact that Roberto had to do all of the paperwork, which cost more than 3,500 C\$, or half the original price of the land.

Roberto and Zulema presently own three pieces of land, all of which have formal individual titles. In addition to this, the family rents land for agriculture and for grazing of their animals: in both cases the land is rented from a friend, a compadre. Roberto hopes to be able to buy the agricultural land, because he and his three sons can cultivate far more land than they have. Consequently, he is already making long-term investments in the land, such as soil and water conservation, partly because he benefits directly from the fertile land, and partly in order to show the compadre that he is taking good care of the land. There are conflicts within the group of heirs to this piece of land, of which the compadre is one, and they may thus opt for selling the land. If Roberto is allowed to buy the land that he currently rents, he will sell the plot that he bought from the co-operative, to help finance the new land purchase.

There is another important reason that has made him consider selling the 6.5 manzana plot of land anyway. A wealthy and powerful military officer, a colonel, has bought most of 
the land that formerly belonged to the co-operative, leaving Roberto's land like an island in the middle of the colonel's ocean of property. To make him sell his land, the colonel threatened to block Roberto's access to his land, which necessarily passes over the colonel's land. Roberto was supported by a group of farmers, who agreed that if the colonel was to block Roberto's access, they would block the colonel from passing over their land to get to his property. When the colonel heard about these plans, he abandoned his threats to block Roberto's access, but he continues to threaten and harass Roberto and his sons. One day they found the colonel's cattle eating the almost ripe sorghum in their field. A part of Roberto's fence had been destroyed to allow the cattle access to Roberto's land. Roberto went straight to the colonel to report the situation, but instead of apologizing and paying compensation, as would be the expected behaviour according to the traditional norms in the village, the colonel became angry and threatened to take the land away from him.

Roberto and Zulema feel that they will have to sell the land, although it is rightfully theirs and they even have a legal, individual title for it, and thus should in principle have the legal system on their side. However, Roberto is not prepared to use the legal system to defend his rights because 'the law is so heavy', as he puts it. He does not want to destroy more social relations and he also realizes that the legal system would be prohibitively expensive. As it is now, he wears a gun whenever he goes to work on that plot of land. The gun is partly a response to threats from the colonel, who has shot at other people that did not want to sell their land, but also to scare people from intruding on his land and stealing the crops, as the land is remote and does not have much protection.

It is clear from Roberto's story that violence and threats are used to influence property transactions, regardless of the legal status of the land, and that the land market is characterized by marked inequalities of wealth and power. As in this case, threats are used to intimidate landowners to try to force or scare them into giving up or selling their land. ${ }^{14}$ Land conflicts are common occurrences; it is not untypical that none of the land transactions that Roberto has been involved in has been free from conflict. Despite having formal titles for the plots of land that he owns, he feels very insecure regarding the tenure situation, especially in the case of the one plot, and he may have to sell the land because of that insecurity. At the same time, however, the insecurity and land conflicts of other families play a role in Roberto's access to other lands - both the land he bought inexpensively from the former land reform beneficiaries, and the land which he currently rents and hopes to buy.

The high costs in both time and money of formal titling and registration of land are also illustrated by Roberto's story. Roberto has paid up to half the original price of the land for the subsequent paperwork of titling and registering. On top of the economic costs, he has spent numerous workdays as well as expenses for travel in the pursuit of land titles. This shows a great willingness to pay for land titles, at least among some farmers who can afford to pay, and thus suggests that formal titles do increase their perceived

14. The impact of threats from a military person such as the colonel has to be interpreted in the light of the more than thirty years of violent dictatorship in Nicaragua prior to the Sandinista Revolution in 1979, as well as the context of contacts, money and power which currently influence decisions in the legal system. 
tenure security. However, it is also clear that formal titles do not provide tenure security in all situations, particularly where the counterpart is wealthier and more powerful. Furthermore, this case illustrates the important role that social networks play in gaining access to land, whether renting or buying, and in the enforcement of one's property rights and thus in tenure security. Here the compadres were especially important for providing access to land.

Finally, Roberto's story shows people's reluctance to involve the formal court system in resolving conflicts. This is due in part to the prohibitively high economic costs, but also in part to social costs, in a context of norms proscribing that conflicts should be solved directly between the parties, without involving the formal system. In fact, the legal system is seldom involved in land conflicts in the case study area. In those rare cases that do come to the courts, the legal system is as likely to intervene in order to threaten the weaker party in the conflict, as to confirm legal rights. Roberto's success in having a case against him suspended is an unusual achievement: this may reflect Roberto's high social status as a successful small-scale farmer and a very active participant in the local Catholic Church.

Doña Petrona and her husband Arnulfo obtained their land through the land reform. $\mathrm{He}$ had formerly worked as a day-worker for the local landowner, and when the co-operative was created after the Revolution, he became a member. Petrona also tried to obtain membership but the president of the co-operative only accepted women to whom he was related. The ordinary members were unaccustomed to having a say and speaking up in larger groups, and the unequal treatment of female applicants was never challenged. Arnulfo worked in the co-operative until it was dissolved and the landholdings were individualized, in 1992. He received the plot of land upon which they currently live as his share of the capital of the co-operative. Originally, he had expected that each member would obtain 5 manzanas of land at the individualization of the co-operative, but he ended up with only half of this amount. This reduction was the result of a large land sale made at the time of division in order to pay off debts to the bank. The debts had been created by only a few of the most influential and best educated members who had obtained loans for themselves, using the collective land reform title as collateral. Arnulfo and (especially) Petrona complained that they all were unfairly forced to help pay the debts of a few members. Unfortunately, being illiterate they felt uncertain about how to proceed and were unable to defend their rights. The co-operative members were presented with a choice between losing all of the co-operative land in foreclosure to the bank, or helping to pay the debts through a land sale, which would allow them to obtain a share of the remaining land. Everybody opted for the last solution, although there is still widespread resentment concerning the incident.

As soon as they were assigned their piece of land, Petrona and Arnulfo moved their house to the plot. By constructing their house there and immediately starting to plant trees and make other investments, they felt more secure that their property right would be respected. Five years later, after a year with good harvests and successful temporary employment as (illegal) immigrants in Costa Rica they obtained a formal, individual title for their plot of land, which means they no longer have to depend on the board of directors of the co-operative and the collective land reform title. They say that they already felt secure before obtaining their land title, as they lived on their land and had invested in it, but that the title always provides a bit more security. Legal papers are considered especially important when the government changes, in case someone from the new government wants to confiscate one's land. 
Petrona and Arnulfo's story illustrates some of the uncertainty related to reformed areas. The insecurity of land tenure in these areas despite their legal land tenure document (a collective land title for the entire co-operative) is partly related to a lack of trust in the government. This lack of confidence was also evident in Roberto's story; it is one reason why beneficiaries of the land reform chose to sell their land rather than run the risk of confiscation or invasion. Thus, both land ownership histories thus illustrate the lack of perceived tenure security provided by the collective land reform title. However, the tenure insecurity in the reformed areas not only relates to lack of trust in the government, but also stems from abuses of power within the co-operative and in society in general, as well as from highly unequal levels of information, education and familiarity with the formal system, whether of banks or courts.

Petrona and Arnulfo's story also shows that investments in land improvements, such as planting trees, soil and water conservation measures, and construction of a house can help strengthen one's tenure security. The increased tenure security provided by these investments is related more to a stronger legitimacy of land rights as perceived by the local community, than to physical structures keeping intruders out. This is an interesting finding, as it opens up the possibility of a causal two-way relationship which contrasts with the commonly accepted uni-directional argument. While the claim of the mainstream tenure literature that tenure security is necessary for the farmer to undertake investment is logically appealing, Petrona and Arnulfo's story illustrates that investments may also be made in order to strengthen tenure security. ${ }^{15}$

\section{Wealth as the Main Source of Tenure Security}

Throughout the field study, people consistently referred to economic wealth as being an important element in ensuring one's property rights. The qualitative data, including Roberto's story, support this, suggesting that economic resources are needed in order to back up the property rights that are assigned in the land title. Without money, it is nearly impossible to obtain assistance from the police or to use the legal system to enforce one's property rights. The extensive use of bribes and corruption, as well as high transaction costs (especially compared to the income of small-scale farmers or the wages of farm-workers) also underscores the importance of wealth. There were several examples in the case study area of people bribing

15. See Braselle et al. (2002), Rose (1994) and Coles-Coghi (1993) for similar findings on the importance of land improvements and land-use for tenure security, and Sjaastad and Bromley (2000) for further discussion of a two-way relationship between investments and security. 
the authorities to get their way, but it is mainly the rich who can afford to pay bribes. The fact that such illegal practices are mentioned openly shows that they are common and quasi-legitimized in today's Nicaragua. Many informants also complained that only the wealthier households have access to the formal system of institutions and land tenure documents. Economic limitations, as well as lack of knowledge of their legal rights, restricted Arnulfo and the other members of the co-operative from seeking legal advice to confront the power abuses of the chairman. Quantitative data from the fieldwork back up the qualitative evidence, indicating that the nonpoor households feel that they have tenure security, while the majority of the poor households perceive their tenure situation as being insecure (Chisquare, $p<0.01$ ), irrespective of titles. Thus, despite expectations among farmers themselves that land titles would provide tenure security, this only seems to happen when land titles are accompanied by economic wealth.

\section{Insecurity Despite Titles, Security Even Without Titles}

The two landownership histories presented above show that while land titles are much desired in order to strengthen property rights, they do not necessarily create tenure security. The stories also illustrate that some households feel sufficiently secure in their tenure arrangements, even without a land title, to make long-term investments in the land, with the explicit goal of strengthening their tenure security as was the case of Petrona and Arnulfo. This is an important example of the complex relationship between different recognitions of property rights, tenure security and investments. This is further supported by quantitative data from La Manzana. Those possessing individual land titles and those holding informal papers both express the same general feeling, with roughly two-thirds of the households in each tenure category considering themselves tenure-secure. No statistically significant relationship was found when performing a cross tabulation of the expressed feeling of tenure security and the two categories of individual titles and informal tenure documents. ${ }^{16}$ These data support the proposition that formal, individual land titles are insufficient to provide tenure security by themselves (at least in an institutional and historical setting such as Nicaragua), and that perceived tenure insecurity does not stem merely from the lack of formal documents.

The qualitative data suggest that elements such as the local legitimacy of property rights, good relations with the previous owner of the land, long duration of possession, and economic wealth all act to influence the level of people's tenure security (see Coles-Coghi, 1993 for similar conclusions in

16. The 'informal tenure document' category also contains households with no tenure documents at all. 
Honduras). As noted above, economic wealth is an important element for enabling households to access the formal tenure institutions which the land title puts at their disposal. As a result, wealthy households tend to feel more tenure security than do other households in La Manzana. A recent countrywide land tenure study in Nicaragua (Merlet and Pommier, 2000) reached similar conclusions.

\section{Worried Land Reform Beneficiaries}

Among the households that depend on collective land reform titles, the majority (roughly three-quarters) perceive their tenure situation as being insecure or worrisome. This is considerably more than for the households having either formal individual titles or informal documents, where only a third feel insecure. This is despite the fact that the collective land reform titles are legally valid documents and were inscribed in the land registry, although admittedly as a collective title. The locally perceived level of legitimacy of the land possession, which among other things is related to land access mechanisms, seems to play a more important role in perceived tenure security than the formality of a land tenure document.

The fact that those who hold informal papers perceive their tenure situation as being no more insecure than those who possess formal tenure documents underscores the importance and strength of social ties in the communities. In general, land that has been obtained individually and land that has belonged to a family for a long time is also perceived as having a relatively high tenure security, regardless of whether legal documents can back up the rights. Land that is assigned to somebody as a result of a powerful person's word of honour is also perceived to be a reliable way of obtaining and maintaining rights to land, despite the fact that there are often no written or legal documents supporting the rights of the present landholder. On the other hand, land obtained through the agrarian reform is perceived to be less secure than any other type of land, despite the legally valid and inscribed (collective) titles (see also de Groot, 1994). There is thus a widespread desire to disengage individual plots from the collective land reform title, and to obtain an individual document, issued by a lawyer, whether or not this can be inscribed in the property registry.

Evidence from the case study area shows that land titles do not provide an equal degree of tenure security to all landholders. It also shows that the lack of an individual land title does not necessarily imply that a situation of insecure tenure exists. Instead, the data suggest that there are multiple sources of (what is locally seen as) legitimacy of property rights, and that formal legitimacy may not provide social legitimacy of property rights. The data from the case study suggest that the degree of perceived tenure security that is created by a land tenure document is more dependent on the local 
legitimacy of the issuing authority than on the legal status of the title. Lawyers, patrónes and family heads who are the issuing authority for the individual titles, informal papers and verbal tenure agreements, enjoy great respect in the case study area. However, there is only limited confidence in the state institutions that have issued the land reform titles. Despite the legal validity of these state-issued documents, the lack of local legitimacy of the land reform titles is reflected in the high degree of perceived tenure insecurity, as expressed by the beneficiaries of the land reform. The frequent incidents of land-grabbing or power abuse by co-operative chairmen also increase the perception of insecurity regarding land with collective land reform title.

\section{CONCLUSION}

The threats to farmers' tenure security are multiple, and may not be equally well prevented with a formal tenure document. The degree to which land titles can actually increase the tenure security depends on the types of threats, household characteristics with respect to economic and social resources, as well as the institutional set-up. How the tenure situation is perceived by the farmer may or may not correspond to an 'objective' evaluation of tenure (in)security, or to the legal tenure status. However, it is argued here that the perceived tenure security, rather than any legal situation of which the landholder may or may not be aware, influences the choices that a landholder makes for investing in land, land use and land sales. The tenure security perceived by the landholder is based on other elements besides the strictly legal tenure situation. Essentially, property relationships must be regarded as a social institution. Consequently, tenure security is best understood as a result of multiple legal, social, economic and power-related elements and their interplay, as well as their specific historic context. The level of tenure security as perceived by the local population is a key element in this new conceptual framework.

Data from the case study demonstrate that the formal land title situation cannot simply be 'translated' into a high degree of tenure security. Some farmers without land titles perceive their tenure situation as being secure, whereas others express tenure insecurity despite their possession of an individual land title. Insecurity is thus created not only by the lack of formal tenure documents, but by inequality, poverty, lack or unequal enforcement of rights, power abuse and the use of violence. The specific historical experience of Nicaragua, including dictatorship until 1979, the politicallymotivated application of the land reform laws during the Sandinista era, and the legal reforms after the 1990 change of government, have also contributed to the present high levels of perceived tenure insecurity.

On this basis, future research should approach the concept of tenure security in a way that also addresses perceived tenure security, even though 
this may require different and more time-consuming methods than using the formal legal status of landholdings alone. Furthermore, using the concept of perceived tenure security as the central analytical element will allow researchers to better understand the links between tenure security and investments by the farmers, in terms of obtaining (or not) a land title, strengthening other social relations, and manoeuvring in a setting of power abuse, conflicts and corruption. Rather than the formal tenurial status, which may be misinterpreted or misunderstood by local farmers after a series of legal reforms, it is the perceived tenure security that forms the basis for people's decisions and actions.

\section{REFERENCES}

Alston, L. J., G. D. Libecap and R. Schneider (1996) 'The Determinants and Impact of Property Rights: Land Titles on the Brazilian Frontier'. National Bureau of Economic Research, Working Paper 5405. NBER Research Program in the Development of American Economy. Cambridge, MA: NBER.

Binswanger, H. P., K. Deininger and G. Feder (1995) 'Power, Distortions, Revolt and Reform in Agricultural Land Relations', in J. Behrmann and T. N. Srinivasan (eds) Handbook of Development Economics, Volume III, pp. 2659-772. Amsterdam: Elsevier.

Braselle, A.-S., F. Gaspart and J-P. Platteau (2002) 'Land Tenure Security and Investment Incentives: Puzzling Evidence from Burkina Faso', Journal of Development Economics 67: 373-418.

Broegaard, R. (2000) 'Land Titles, Tenure Security and Land Improvements. A Case-study in Carazo, Nicaragua'. Geographica Hafniensia C10, Institute of Geography. Copenhagen: University of Copenhagen.

Broegaard, R. (2005) 'Inseguridad de tenencia y conflictos de propiedad en Nicaragua'. Research consultancy concerning land tenure insecurity, land conflicts, decentralization and the environmental impact of land regularization and tenure security in Nicaragua. Report I. WB UPI No. 0000246858, Purchase Order No 7590565. Financed by the Danish Consultant Trust Fund.

Bromley, D. W. (1991) Environment and Economy. Property Rights and Public Policy. Oxford: Blackwell.

Bruce, J. W. and S. E. Migot-Adholla (eds) (1994) Searching for Land Tenure Security in Africa. Dubuque, IA: Kendall/Hunt Publishing Company.

Carter, M. R. and P. Olinto (2003) 'Getting Institutions "Right" for Whom? Credit Constraints and the Impact of Property Rights on the Quantity and Composition of Investment', American Journal of Agricultural Economics 85(1): 173-86.

CENAGRO (2001) 'Censo Nacional Agropecuario'. Instituto Nacional de Estadísticas y Censos. Nicaragua. Available online: http://www.inec.gob.ni/cenagro/presentacionce.htm

Coles-Coghi, A. (1993) 'Agricultural Land Rights and Title Security in Honduras'. PhD thesis, University of Wisconsin-Madison.

Deininger, K. (1999) 'Making Negotiated Land Reform Work: Initial Experience from Colombia, Brazil and South Africa', World Development 27(4): 651-72.

Deininger, K. and J. S. Chamorro (2002) 'Investment and Income Effects of Land Regularization. The Case of Nicaragua'. Policy Research Working Paper No 2752. Washington, DC: The World Bank; Madison, WI: University of Wisconsin-Madison.

Deininger, K., E. Zegarra and I. Lavadenz (2003) 'Determinants and Impacts of Rural Land Market Activity: Evidence from Nicaragua', World Development 31(8): 1385-1404.

EIU (2001) Country Profile. Nicaragua 2001. London: The Economist Intelligence Unit. 
Feder, G. and D. Feeny (1991) 'Land Tenure and Property Rights: Theory and Implications for Development Policy', The World Bank Economic Review 5(1): 135-53.

Feder, G., T. Onchan, Y. Chalamwong and C. Hongladarom (1988) Land Policies and Farm Productivity in Thailand. Baltimore, MD: The Johns Hopkins University Press in association with the World Bank.

Freeden, M (1991) Rights. Buckingham: Open University Press.

de Groot, J. P. (1994) 'Reforma Agraria en Nicaragua: Una Actualización', in J. P. de Groot and M. Spoor (eds) Ajuste Estructural y Economía Campesina: Nicaragua, El Salvador, Centroamerica, pp. 97-122. Managua: Escuela de Economía Agrícola, UNAN.

GTZ (1998) 'Land Tenure in Development Cooperation. Guiding Principles'. Schriftenreihe der GTZ, 264. Wisbaden: Universum Verlagsanstalt.

Jansen, K. and E. Roquas (1998) 'Modernizing Insecurity: The Land Titling Project in Honduras', Development and Change 29(1): 81-106.

Jonakin, J. and L. J. Enríquez (1999) 'The Non-Traditional Financial Sector in Nicaragua: A Response to Rural Credit Market Exclusion', Development Policy Review 17(2): 141-69.

Juul, K. and C. Lund (eds) (2002) Negotiating Property in Africa. Portsmouth, NH: Heinemann. de Laiglesia, J. R. (2004) 'Investment and Credit Effects of Land Titling and Registration: Evidence from Nicaragua'. London: London School of Economics (mimeo). Available online: http://econ.lse.ac.uk/phdc/otherfiles/DeLaiglesiaJMpaper.pdf

Lemel, H. (1988) 'Land Titling: Conceptual, Empirical and Policy Issues', Land Use Policy 5(3): 273-90.

Li, T. M. (1996) 'Images of Community: Discourse and Strategy in Property Relations', Development and Change 27(3): 501-27.

Lund, C. (2001) 'Seeking Certainty and Aggravating Ambiguity: On Property, Paper and Authority in Niger', IDS Bulletin 32(4): 47-53.

Merlet, M. and D. Pommier (2000) 'Estudios sobre la tenencia de la tierra'. Study carried out for Office for Rural Titling (OTR) and the World Bank. Managua: IRAM (Institut de Recherches et d'Aplications de Méthodes de développement).

Migot-Adholla, S., P. Hazell, B. Blarel and F. Place (1991) 'Indigenous Land Rights Systems in Sub-Saharan Africa: A Constraint on Productivity?', The World Bank Economic Review 5(1):155-75.

Moore, S. F. (1999) 'Changing African Land Tenure: Reflections on the Incapacities of the State', in C. Lund (ed.) Development and Rights. Negotiating Justice in Changing Societies, pp. 33-49. London: Frank Cass.

Nuijten, M. (2003) 'Illegal Practices and the Re-Enchantment of Governmental Techniques: Land and the Law in Mexico', Journal of Legal Pluralism 48: 163-83.

Ostrom, E. (1990) Governing the Commons. The Evolution of Institutions for Collective Action. Cambridge: Cambridge University Press.

Ostrom, E. (2001) 'The Puzzle of Counterproductive Property Rights Reforms: A Conceptual Analysis', in A. de Janvry, G. Gordillo, J-P. Platteau and E. Sadoulet (eds) Access to Land, Rural Poverty, and Public Action, pp. 129-50. Oxford: Oxford University Press.

Pagiola, S. (1999) 'Economic Analysis of Rural Land Administration Projects'. Land Policy and Administration Thematic Team, Environment Department. Washington, DC: The World Bank.

Place, F. and P. Hazell (1993) 'Productivity Effects on Indigenous Land Tenure Systems in SubSaharan Africa', American Journal of Agricultural Economics 75(1): 10-19.

Place, F., M. Roth and P. Hazell (1994) 'Land Tenure Security and Agricultural Performance in Africa: Overview of Research Methodology', in J. W. Bruce and S. E. Migot-Adholla (eds) Searching for Land Tenure Security in Africa, pp. 15-39. Dubuque, IA: Kendall/Hunt Publishing Company.

Ravnborg, H. M. (1999) 'Developing Regional Poverty Profiles Based on Local Perceptions'. CIAT Publication 291. Cali: Centro International de Agricultura Tropical. 
Roquas, E. (2002) Stacked Law. Land, Property and Conflict in Honduras. Amsterdam: Rosenberg Publishers.

Rose, C. M. (1994) Property \& Persuasion. Essays on the History, Theory and Rhetoric of Ownership. Boulder, CO: Westview Press.

Sjaastad, E. and D. W. Bromley (1997) 'Indigenous Land Rights in Sub-Saharan Africa: Appropriation, Security and Investment Demand', World Development 25(4): 549-62.

Sjaastad, E. and D. W. Bromley (2000) 'The Prejudices of Property Rights: On Individualism, Specificity, and Security in Property Regimes'. Development Policy Review 18(4): 365-89.

SPSS (1994) SPSS Categories 6.1. Chicago: SPSS Inc.

Stanfield, J. D. (1995) 'Insecurity of Land Tenure in Nicaragua'. LTC Research Paper 120. Madison, WI: Land Tenure Center, University of Wisconsin-Madison.

Stanfield, D. J. and S. E. Hendrix (1993) 'Ownership Insecurity in Nicaragua', Capital University Law Review 22: 939-63.

Stanfield, D., R. Zeledón, S. Moquete, A. Coles, M. Fandiño, L. Caballero and R. Stringer (1986) 'Land Titling in Honduras: A Midterm Evaluation of the Small Farmer Titling Project in Honduras'. Project No 522-0173. Madison, WI: Land Tenure Center, University of Wisconsin-Madison.

Wachter, D. (1997) 'Land Titling and Prospects for Land Conservation: Lessons from a CaseStudy in Honduras', in J. P. de Groot and R. Ruben (eds) Sustainable Agriculture in Central America, pp. 181-90. London: Macmillian.

World Bank (1999) World Development Report. Knowledge for Development. New York: Oxford University Press.

Rikke J. Broegaard is currently undertaking research for a $\mathrm{PhD}$ in International Development Studies at Roskilde University and the Danish Institute for International Studies, Strandgade 56, 1401 Copenhagen K, Denmark (e-mail: rjb@diis.dk). Her research revolves around land tenure security, inequity, and negotiations over land and natural resources in Latin America. 